\title{
ASPEK HUKUM PERLINDUNGAN KONSUMEN MUSLIM DI INDONESIA
}

Ashabul Kahpi Universitas Islam Negeri (UIN) Alauddin Makassar

Email: cavon.al@gmail.com

\section{Abstract}

Majority resident of Indonesia is moslem, with this fact can be expressed that biggest consumer of Indonesia is Islam people. Related to fact, hence have goods ought to which consumed ( food, cosmetic, oil lamp goods and also obatobatan and of gunaan other), is obliged to fulfill specified by standards is Islamic Religion, covering thayyiban halalan, mubaaraqan. For that Government of Indonesia as assumed side. Most responsibility have released and specify various related law product of the mentioned, despitefully is also founded various institutes for example MUI with LP POM-NYA, Body of POM, YLKI, Body Organizer of Lawful Product, and also other institute. Still lawful related/relevant policy and illegality a[n product also [go/come] home [at] policy and carefulness of Islam people as consumer.

\section{Key Word : Lawful Product, Moslem Consumer, Law Guarantee}

\begin{abstract}
Abstrak
Mayoritas penduduk Indonesia adalah muslim, dengan fakta ini dapat dinyatakan bahwa konsumen terbesar Indonesia adalah umat Islam. Terkait dengan fakta tersebut, maka sudah seharusnya barang-barang yang dikonsumsi (makanan, kosmetik, obat-obatan maupun barang sedian dan gunaan lainnya), wajib memenuhi standar-standar yang ditetapkan Agama Islam, meliputi halalan thayyiban, mubaaraqan. Untuk itu Pemerintah Indonesia sebagai pihak yang dianggap paling bertanggungjawab telah mengeluarkan dan menetapkan berbagai produk hukum terkait hal tersebut, disamping itu pula didirikan berbagai lembagalembaga semisal MUI dengan LP POM-nya, Badan POM, YLKI, Badan Penyelenggara Produk Halal, maupun lembaga lainnya. Meski demikian kebijakan terkait kehalalan dan keharaman suatu produk juga berpulang pada kebijakan dan kehati-hatian umat Islam sebagai konsumen.
\end{abstract}

Kata Kunci : produk halal, konsumen muslim, jaminan hukum 


\section{PENDAHULUAN}

$\mathrm{M}$

akanan (pangan) merupakan kebutuhan mendasar bagi setiap manusia, berdampingan dengan kebutuhan primer lainnya berupa sandang dan papan. Akan tetapi makanan saja tidak lantas memberikan jaminan hidup pada manusia jika standar dan kualitas pangan yang dikonsumsi jauh dari kata layak, lebih khusus lagi bagi masyarakat muslim. Bahwa bagi kaum muslim, standar kelayakan tersebut tidak hanya diukur berdasarkan bergizi dan tidaknya suatu produk pangan atau dari aspek higienitas semata akan tetapi standar yang paling utama adalah ke-halalan produk tersebut.

Pedoman konsumsi dalam Islam seperti yang dikemukakan di dalam al Qur'an adalah halal dan baik (thoyyib) $)^{l}$. Bahwa yang disebut sebagai "layak" syarat utamanya haruslah sesuatu yang halal, artinya tidak terdapat larangan agama atau Allah tidak mengharamkannya. Oleh sebab itu, jika berpedoman pada kehalalan produk yang dikonsumsi akan tampak bahwa jenis-jenis makanan maupun minuman yang diharamkan dalam Islam sangatlah sedikit. Sementara untuk thoyyib atau sesuatu yang "baik" adalah baik dari aspek kesehatan, keamanan, kelezatan, nilai gizi, estetika dan lainnya dikembalikan kepada manusia dan merupakan hak manusia untuk menetapkannya, berdasarkan kajian para pakar di bidang tersebut.

Tidak dapat dipungkiri, tehnologi pengolahan makanan, kosmetik dan obat obatan telah berkembang sedemikian pesatnya yang melibatkan proses yang kompleks dan terkadang rumit serta dengan keragaman bahan-bahan bakunya, menjadikan permasalah makanan, obat obatan dan kosmetik tidak lagi sederhana. Oleh sebab itu konsep halal dan baik tersebut, sejatinya telah berkembang tidak hanya terhadap makanan semata, akan tetapi segala sesuatu yang dikonsumsi baik secara langsung atau melalui suatu proses produksi. Dengan demikian pengertian halal dan baik tersebut meliputi minuman, kosmetik, obat-obatan serta barang guna-an lainnya, di samping jaminan bahwa dalam proses-proses produksi tidak terdapat cara (proses) dan bahan bahan yang diharamkan (misalnya sepatu dari kulit babi)

Sebagai negara yang mayoritas penduduknya beragama Islam $^{2}$, maka Indonesia dituntut untuk menempatkan permasalahan penyediaan dan ketersediaan produk-produk halal pada posisi penting. Perlindungan dan jaminan hukum atas keharaman atau kehalalan suatu produk yang dikonsumsi oleh masyarakat muslim di Indonesia adalah hak individu sekaligus hak sebagai warga

${ }^{1}$ Lihat QS Al Baqarah : 168, maupun QS al Maaidah : 88

${ }^{2}$ Berdasarkan data Proyeksi Penduduk Badan Statistik 2017 yaitu 228.608.665 
negara, oleh sebab itu, baik produksi dalam negeri maupun produk impor, adalah menjadi kewajiban dan tanggung jawab pemerintah untuk memberikan rasa aman dan ketentraman bagi konsumen dalam mengkonsumsi atau menggunakan berbagai produk olahan. Menurut $\mathrm{Ujang}^{3}$, bahwa kebutuhan dan pengetahuan konsumen terhadap suatu produk sangat penting artinya dalam proses pratransaksi agar konsumen mendapatkan manfaat dan tidak dirugikan oleh suatu produk

Pada hakikatnya, mengetahui dan mengontrol sendiri barang-barang yang hendak dikonsumsi adalah tanggung jawab dan kewajiban masing-masing individu, terlepas dari agama yang dianutnya. Akan tetapi lahirnya berbagai produk olahan inovatif dan variatif baik berupa makanan, kosmetik, obat-obatan, serta barang guna-an lainnya, akhirnya menempatkan konsumen berada pada posisi memilih dan memakai sesuai selera tanpa perlu tahu bahan dan prosesnya. Belum lagi iklan-iklan produk yang massif di berbagai media yang disertai penggunaan publik-publik figur tertentu dan iming-iming hadiah justru terkadang menjadikan "halal dan baik" terlupakan ${ }^{4}$. Parahnya lagi, iklan-iklan produk hanya menunjukkan manfaat dan kelebihan tanpa disertai informasi terkait kekurangankekurangan tertentu ${ }^{5}$ terutama terkait keamanan dan kenyamanan produk ${ }^{6}$

Sebagai gambaran, bahwa ketika kasus "lemak babi" menyeruak kepermukaan, maka pada tahun 2000 produk pangan saja yang berlabel halal hanya sekira $10 \%$, belum lagi produk gunaan lainnya. ${ }^{7}$ Lalu bagaimana dengan (90\%) produk pangan dan produk gunaan lainnya?. Pertanyaan ini mungkin terlihat biasa bagi negara yang warga negaranya bukan mayoritas muslim. Lain halnya bagi Indonesia yang mayoritas muslim, meski produk yang akan dikonsumsi dikembalikan kepada konsumen, akan tetapi diperlukan ketelitian

\footnotetext{
${ }^{3}$ Ujang Sumarwan, Perilaku Konsumen, Teori dan Penerapannya Dalam Pemasaran, (Bogor, Ghalia, 2011), h. 158

4 Kasus haramnya ajinomoto yang heboh pada tahun 2000 yang sebelumnya telah dinyatakan halal, justru merupakan lanjutan kehebohan produk-produk lainnya pada tahun 1988 terkait isu "lemak babi". Ternyata keraguan sebagian umat Islam masih berlanjut sampai sekarang, terbukti dengan munculnya kembali "babi" pada produk yang sama pada tahun 2016. Meski terakhir diklarifikasi kembali oleh MUI (lihat berita klarifikasi MUI pada https://food.detik.com/info-halal/d-3384854/ini-klarifikasi-mui-terkait-kehalalan-produk-bumbupenyedap-dan-mie-goreng-instan)

${ }^{5}$ Dedi Harianto, Perlindungan Hukum Bagi Konsmen Terhadap Iklan yang Menyesatkan, (Bogor, Ghalia, 2010), h. 5

${ }^{6}$ Dedi Harianto, Perlindungan Hukum Bagi Konsmen Terhadap Iklan yang Menyesatkan, h. 5

${ }^{7}$ Departrmen Agama, Pedoman Produk Halal, ( Jakarta, Proyek Pembinaan Pangan Halal,2003), h. 5
} 
untuk tidak sekedar memilih produk, akan tetapi konsumen perlu mengetahui bahan-bahan serta proses terkait suatu produk. Meski demikian, pengetahuan yang dimiliki konsumen kadang sangat terbatas ${ }^{8}$, bahkan tidak ada sama sekali. Pada sisi inilah pemerintah dan pelaku usaha berkewajiban untuk memberikan jaminan dan ketentraman bagi kaum muslim untuk memilih produk yang akan dikonsumsi atau digunakan. Menjadi kewajiban pemerintah pula untuk terus melakukan pengawasaan dan penegakan hukum terhadap pelaksanaan peraturan yang telah ditetapkan.

Mencermati berbagai kehebohan halal-haram terkait produk-produk yang beredar di masyarakat, maka salah satu aspek HAM yang hingga kini belum tersentuh secara baik dalam perlindungan dan penegakan HAM adalah perlindungan konsumen. Implikasinya semakin menghawatirkan, karena akselerasi pemberdayaan masyarakat di bidang konsumen dan HAM masih sangat kurang dilaksanakan. Sementara produsen lebih mementingkan keuntungan perusahaan ditengah persaingan yang semakin ketat dan mengabaikan kepentingan konsumen. Oleh karena itu, Pemerintah wajib ikut ambil bagian dalam mengatur dan mengawasi peredaran produk makanan kemasan di pasar yang tidak memenuhi persyaratan mutu, keamanan dan khasiat. Hal ini dapat dilihat dengan diterbitkannya Undang - Undang Nomor 8 Tahun 1999 tentang Perlindungan Konsumen, yang diharapkan dapat menjamin tercapainya penyelenggaraan perlindungan konsumen.

\section{PEMBAHASAN}

Maraknya produk-produk olahan dan kemasan, baik produk dalam negeri maupun impor, menjadikan konsumen bebas memilih dan memilah produkproduk yang hendak dikonsusinya. Akan tetapi pada aspek lainnya, kehalalan akan maraknya produk-produk tersebut justru sangat rawan. Oleh sebab itu dalam kegiatan produksi dan perdagangan di era globalisasi dan pasar bebas, masyarakat konsumen, khususnya masyarakat muslim perlu diberikan pengetahuan, informasi dan akses yang memadai untuk memperoleh informasi yang benar dan tidak menyesatkan tentang status kehalalan produk yang dikonsumsinya, utamanya produk pangan. Di samping kerjasama ulama, umara dan ilmuan dalam menentukan "halalnya" suatu produk mengingat permasalahan ini memerlukan

\footnotetext{
${ }^{8}$ Kembali pada kasus MSG, meski sebagian masyarakat tahu MSG itu vetsin akan tetapi hanya orang tertentu saja yang mengetahui prosesnya, terlebih mengetahui apa itu enzim porcine protease, Bacto Soytone atau istilah kimia lainnya.
} 
pengetahuan yang mendalam mengenai asal-usul bahan produksi di samping pengetahuan fiqhi.

\section{A. Hukum Islam dan Hukum Positif Terkait Halal-Haram}

1. Hukum Islam

Secara spesifik Islam tidak menunjukkan adanya perintah untuk memberikan labelisasi halal pada berbagai produk. Akan tetapi keharusan ini merupakan konstruksi Ijtihady yang justru menjadi mutlak adanya. Sebagai yang dikemukakan oleh Murjani bahwa Konstruksi ijtihadi -maslahah mursalahmerupakan konsep dasar pijakan yang tepat diambil guna memberikan justifikasi atas kebijakan jaminan produk halal. Legal reasoningnya terletak pada "kulliyatul khamsah", bahwa dari aspek terpeliharanya kewajiban menjalankan syari'at hifzu diin - yakni secara aqidah jaminan halal menjadi harga mati bagi masyarakat muslim, mengingat ini menjadi tuntunan, tuntutan dan kewajiban ibadah kepada Allah. ${ }^{9} \quad$ Sementara itu, dalam bukunya Halal dan Haram Yusuf Qardawi menjelaskan beberapa prinsip-prinsip Islam tentang Halal dan haram sebagai berikut $^{10}$ :

a. Segala sesuatu pada asalnya adalah mubah. Dalam Islam segala sesuatu itu adalah halal dan boleh dan tidak ada yang haram sampai/terkecuali ada nash/dalil yang tegas dari Pembuat Syari'at yang mengharamkannya.

b. Halal-haram adalah hak Allah semata. Peran ulama dalam hal ini adalah merumuskan dan menjabarkan lebih lanjut hal-hal yang telah ditegaskan oleh Allah swt. ${ }^{11}$

c. Mengharamkan yang halal akan mengakibatkan timbulnya keburukan dan bahaya

d. Sesuatu yang halal tidak memerlukan yang haram

e. Sesuatu yang membawa kepada yang haram adalah haram, misalnya dalam masalah khamar, Rasul melaknat peminumnya, pembuatnya, penghidangnya dan mereka yang memakan hasil (dari) usaha khamar.

f. Bersiasat terhadap yang haram adalah haram

g. Niat baik tidak dapat menghalalkan sesuatu yang haram

h. Menjauhkan diri dari syubhat karena takut terjatuh dalam keharaman

${ }^{9}$ Murjani, Sistem Jaminan Produk Halal dan Thayib di Indonesia: Tinjauan Yuridis dan Politis. Jurnal Fenomena Volume 7, No. 2 Tahun 2015, h. 215

${ }^{10}$ Departrmen Agama, Pedoman Produk Halal, h, 9-24

${ }^{11}$ Lihat firman Allah dalam QS Yunus : 59 
i. Sesuatu yang haram berlaku untuk semua orang

j. Keadaan terpaksa membolehkan yang terlarang. ${ }^{12}$

Dalam Islam, terdapat banyak perintah (melalui al Qur'an) yang memerintahkan untuk memakan dan mengkonsumsi hanyalah sesuatu yang halal lagi baik. Selain itu, al Qur'an menjelaskan pula makanan yang diharamkan sesuai dengan ayat 173 QS Al Baqarah, bahwa sesungguhnya Allah mengharamkan bagi umat Islam yaitu bangkai, darah, daging babi dan binatang yang disembelih tidak dengan menyebut nama Allah. Selain keempat jenis makanan tersebut, terdapat barang /makanan yang haram dikonsumsi karena sifatnya yang buruk dan menjijikkan, sebagai yang dijelaskan dalam QS al A'raf : 157 ... dan menghalalkan bagi mereka segala yang baik dan mengharamkan bagi mereka segala yang buruk. Hal-hal yang buruk lalu dicontohkan oleh Rasulullah melalui haditsnya, di antaranya hadits Ibnu Abbas yang menyatakan bahwa Rasulullah telah melarang memakan tiap-tiap binatang buas yang bersaing (bertaring) dan yang mempunyai kuku pencengkraman dari burung. ${ }^{13}$ Oleh sebab itu, disamping konsep halal haram baik yang langsung disebutkan secara jelas maupun secara tersamar, dalam Islam juga dikenal konsep/kategori makanan halal dan seluruh kategori tersebut harus dipenuhi agar makanan layak dikatakan sebagai makanan halal Adapun kategori dan hal-hal tersebut antara lain :

\section{a. Halal zatnya}

Hal pertama yang harus diperhatikan dalam penentuan kehalalan suatu makanan adalah zat nya atau bahan dasar makanan tersebut misalnya makanan yang berasal dari binatang maupun tumbuhan yang tidak diharamkan oleh Allah. Adapun jika dalam makanan disebut terkandung zat atau makanan yang tidak halal maka status makanan yang tercampur tersebut adalah haram dan tidak boleh dikonsumsi oleh umat Islam.

\section{b. Halal cara memperolehnya}

Pada dasarnya semua makanan adalah halal dan apabila zatnya halal maka makanan dapat menjadi haram tergantung bagaimana cara memperolehnya. Makanan halal dapat menjadi haram apabila diperoleh melalui hasil mencuri, melalukan perbuatan zina, riba dan maupun korupsi dan lain sebagainya.

\section{c. Halal cara memprosesnya}

Kategori halal yang harus dipenuhi selanjutnya adalah cara memproses makanan tersebut. Apabila makanan sudah diperoleh dengan cara halal,

\footnotetext{
${ }^{12}$ Lihat QS al Baqarah : 173

${ }^{13}$ Sayyid Sabiq, Fikih Sunnah, Jilid 13 (Bandung, al Ma'arif, 1999), h. 109
} 
dengan bahan baku yang halal pula, jika makanan tersebut diproses dengan menggunakan sesuatu yang haram misalnya alat masak yang bekas digunakan untuk memasak makanan haram atau bahan-bahan lain yang tidak diperbolehkan atau diharamkan untuk dikonsumsi maka makanan tersebut bisa menjadi haram.

\section{d. Halal mengantarkan serta menyimpannya}

Kategori halal yang terakhir adalah bagaimana makanan tersebut disimpan, diangkut sebelum akhirnya dikonsumsi. proses tersebut dapat mengubah status makanan dari halal menjadi haram misalnya jika makanan disimpan bersamaan/bercampur dengan makanan haram dan diantar untuk tujuan yang tidak baik. ${ }^{14}$

e. Halal dalam Penyajian.

Dalam mengedarkan dan menyajikan makanan penyajinya haruslah bersih dari najis dan kotoran. Para supplier dan leveransir atau sales haruslah orang yang sehat dan berpakaian bersih dan suci. Alat kemas atau bungkus atau yang sejenisnya harus hygenis, steril, bersih, suci dan halal. Perkakas atau alat hidangan seperti piring, mangkok dan sebagainya haruslah suci, bersih dan halal. ${ }^{15}$

\section{Hukum Positif}

Secara khusus, hukum positif yang mengatur sistem sertifikasi dan labelisasi halal belum ada, akan tetapi menurut sebagian kalangan, bahwa setelah tahun 2014, Indonesia telah memeliki aturan khusus terkait kehalalan suatu produk yaitu melalui Undang-undang No. 33 Tahun 2014 Tentang Jaminan Produk Halal. Meski demikian dari aspek hukum positif ini, pemerintah Indonesia telah berusaha meIindungi hak asasi umat Islam dalam memperoleh jaminan halal atas konsumsi makanan, minuman, kosmetika, dan obat-obatan dengan mengeluarkan sejumlah peraturan dalam bentuk undang-undang, peraturan pemerintah, serta instruksi presiden. di antaranya:

a. Undang-undang No. 36 Tahun 2009 Tentang Kesehatan. Pada Pasal 4 undang-undang ini dinyatakan bahwa setiap orang berhak atas kesehatan. Pengertian sehat/kesehatan dalam undang undang ini adalah Kesehatan adalah keadaan sehat, baik secara fisik, mental, spritual

${ }^{14}$ https://dalamislam.com/makanan-dan-minuman/makanan-halal/makanan-halal, 14 Mei 2018

${ }^{15}$ Murjani, Sistem Jaminan Produk Halal dan Thayib di Indonesia: Tinjauan Yuridis dan Politis. Jurnal Fenomena Volume 7, No. 2 Tahun 2015, h. 213 
maupun sosial yang memungkinkan setiap orang untuk hidup produktif secara sosial dan ekonomis. ${ }^{16 "}$

Bahwa kesehatan seseorang dapat tergantung pada makanan atau minuman yang mereka konsumsi, oleh sebab undang-undang ini merumuskan hal yang terkait dengan makanan dan minuman berupa "pengamanan makanan dan minuman" dalam bagian ke 16 Bab VI.

Pasal 112 menyatakan bahwa Pemerintah berwenang dan bertanggung jawab mengatur dan mengawasi produksi, pengolahan, pendistribusian makanan,dan minuman sebagaimana dimaksud dalam Pasal 109, Pasal 110, dan Pasal 111.

Adapun Pasal 109 menyatakan bahwa Setiap orang dan/atau badan hukum yang memproduksi, mengolah, serta mendistribusikan makanan dan minuman yang diperlakukan sebagai makanan dan minuman hasil teknologi rekayasa genetik yang diedarkan harus menjamin agar aman bagi manusia, hewan yang dimakan manusia, dan lingkungan.

Sementara standar, syarat dan labelisasi produk diatur berdarkan Pasal 111, yaitu : Makanan dan minuman yang dipergunakan untuk masyarakat harus didasarkan pada standar dan/atau persyaratan kesehatan.

1) Makanan dan minuman hanya dapat diedarkan setelah mendapat izin edar sesuai dengan ketentuan peraturan perundang-undangan.

2) Setiap makanan dan minuman yang dikemas wajib diberi tanda atau label yang berisi:

a) Nama produk;

b) Daftar bahan yang digunakan;

c) Berat bersih atau isi bersih;

d) Nama dan alamat pihak yang memproduksi atau memasukan makanan dan minuman kedalam wilayah Indonesia; dan

e) Tanggal, bulan dan tahun kadaluwarsa.

3) Pemberian tanda atau label sebagaimana dimaksud pada ayat (1) harus dilakukan secara benar dan akurat.

4) Ketentuan lebih lanjut mengenai tata cara pemberian label sebagaimana dimaksud pada ayat (3) dilakukan sesuai dengan ketentuan peraturan perundangundangan.

5) Makanan dan minuman yang tidak memenuhi ketentuan standar, persyaratan kesehatan, dan/atau membahayakan kesehatan

${ }^{16}$ Selanjutnya lihat Pasal 1 ayat 1 UU Kesehatan 
sebagaimana dimaksud pada ayat (1) dilarang untuk diedarkan, ditarik dari peredaran, dicabut izin edar dan disita untuk dimusnahkan sesuai dengan ketentuan peraturan perundangundangan.

b. Undang-undang No. 18 Tahun 2012. Undang-undang ini pada pokoknya berkaitan dengan :

1) Persyaratan teknis tentang pangan, meliputi ketentuan kemanan pangan, mutu, gizi, labelisasi dan iklan pangan sebagai suatu sistem standarisasi pangan yang bersifat menyeluruh

2) Tanggung jawab setiap pihak yang memproduksi, menyimpan, dan atau mengedarkan pangan serta sanksi hukum untuk mendorong pemenuhan atas ketentuan yang ditetapkan

3) Peranan pemerintah dan masyarakat dalam mewujudkan tingkat kecukupan pangan dalam negeri dan penganekaragaman pangan yang dikonsumsi secara tidak bertentangan dengan keyakinan masyarakat

4) Tugas pemerintah untuk membinan serta mengembangkan industri pangan nasional.

Terkait kehalalan yang dipersyaratkan (bila diperlukan), termuat dalam aturan terkait labelisasi. Pasal 96 ayat (1 dan 2) yang menyatakan bahwa pemberian label dimaksudkan untuk memberikan informasi yang jelas dan benar bagi masyarakat terkait asal, keamanan, mutu, kandungan gizi, serta informasi lain yang dibutuhkan ${ }^{17}$. Informasi tentang "produk halal" masuk dalam kategori "informasi lain", sebab ada kalanya suatu produk dianggap tidak memerlukan label (keterangan) halal jika produk (nama) tersebut sudah memuat keterangan yang dipersyaratkan, misalnya produk olahan yang jelasjelas mencantumkan daging babi sebagai bahan utamanya(bacon, salami, ham). Akan tetapi masalahnya ada pada produk yang dalam prosesnya menggunakan bahan-bahan yang diragukan (misalnya MSG), maka mencantumkan label (halal) menjadi kewajiban bagi pihak produsen. Selanjutnya pasal 97 menegaskan tentang kewajiban untuk memberikan label bagi produk (pangan) yang diperdagangkan baik berasal dari dalam negeri maupun produk impor, sedikitnya harus

${ }^{17}$ Republik Indonesia, Undang-Undang No. 18 Tahun 2012 Tentang Pangan. Pasal 96 ayat (1 dan 2) 
memuat nama, bahan, berat, halal (bagi yang dipersyaratkan) ${ }^{18}$, alamat produsen atau pengimpor, asal-usul pangan tertentu, nomor registrasi, tanggal kadaluarsa dan izin edar dan harus ditulis cetak dan tegas agar mudah difahami oleh konsumen ${ }^{19}$. Patut dicermati bahwa ketentuan Pasal 97 tersebut tidak berlaku bagi perdagangan pangan yang dibungkus/dikemas di hadapan pembeli/konsumen ${ }^{20}$, oleh sebab itu keadaan halal dan haramnya produk pangan tersebut di satu pihak menjadi tanggung jawab penjual dan seharusnya inklusif berdasarkan Pasal $101^{21}$, dan dipihak lain berada di tangan konsumen untuk kecermatan memilih produk pangan yang hendak dibelinya. Menyikapi hal tersebut, maka bagi pelaku usaha khususnya yang langsung berhadapan dengan konsumen hendaknya :

1) Mempunyai itikad baik dalam kegiatan usahanya

2) Bersedia memberikan informasi yang benar, jelas, terbuka dan jujur mengenai kondisi dan jaminan atas produknya, termasuk status kehalalan

3) Menjamin mutu produk yang diperdagangkan telah sesuai dengan standar dan ketentuan yang berlaku/dipersyaratkan

4) Memberi kesempatan kepada konsumen untuk menguji/mencoba barang dan/atau jasa tertentu ${ }^{22}$

c. Undang-Undang No. 33 Tahun 14 Tentang Jaminan Produk Halal (UU JPH)

Indonesia sebagai negara dengan mayoritas penduduknya adalah muslim, jelas merupakan sasaran empuk bagi pasaran produk dunia. Dengan diterapkannya era pasar bebas, maka produk-produk impor (makanan, minuman dan produk gunaan lainnya) membanjiri Indonesia, yang pada sisi ekonomi akan menjadi ancaman bagi daya

${ }^{18}$ Label halal bagi yang dipersyaratkan tidak dijelaskan dalam undang-undang ini (cukup jelas), namun pada undang-undang sebelumnya (UU No. 7 Tahun 1996), dinyatakan bahwa keterangan halal untuk suatu produk pangan sangat penting bagi masyarakat Indonesia yang mayoritas Islam, namun hal ini baru merupakan kewajiban jika produk pangan yang diproduksi dan diimpor adalah halal bagi umat Islam... Lihat penjelasan Pasal 30 ayat 2 (e).

${ }^{19}$ Republik Indonesia, Undang-Undang No. 18 Tahun 2012, Pasal 97 ayat (1,2,3 dan 4)

${ }^{20}$ Republik Indonesia, Undang-Undang No. 18 Tahun 2012, Pasal 98 ayat (2)

${ }^{21}$ Lihat Republik Indonesia, Undang-Undang No. 18 Tahun 2012, Pasal 101 ayat (1)

${ }^{22}$ Kementrian Agama RI, Pedoman Libelisasi Halal, (Jakarta, Proyek Pembinaan Pangan Halal Dirjen Binmas Islam, 2003), h. 7 
saing produk dalam negeri dan pada sisi lain menimbulkan kekhawatiran dan keraguan terhadap kehalalan suatu produk. Oleh karena itu pemerintah dituntut untuk menciptakan produk hukum yang dapat menjamin keamanan dan kenyamanan konsumen, terkhusus bahwa produk tersebut halal bagi umat Islam terlebih lagi bahwa labelisasi halal sangat tergantung pada kesadaran produsen

Hal-hal seperti tersebut lantas menjadi dasar bagi negara yang akhirnya membuat undang-undang tentang jaminan produk halal. Pemerintah beranggapan bahwa tidak semua produk yang beredar di masyarakat terjamin kehalalannya ${ }^{23}$ oleh sebab itu bahwa untuk menjamin setiap pemeluk agama untuk beribadah dan menjalankan ajaran agamanya, negara berkewajiban memberikan pelindungan dan jaminan tentang kehalalan produk yang dikonsumsi dan digunakan masyarakat, disamping perlu adanya jaminan kepastian hukum ${ }^{24}$

Perjalanan UU JPH ini tidaklah mulus dan lapang, akan butuh waktu sangat lama bagi pengurusan sebuah undang-undang. Penolakan dari sejumlah pengusaha yang tak paham sempat terjadi ${ }^{25}$, bahkan masih terdengar hingga kini. Namun tak mampu menghentikan laju terbitnya payung hukum bagi konsumen muslim. Setelah penyusunan naskah akademik Rancangan Undang-Undang Jaminan Produk Halal (RUU JPH) pada tahun 2006, RUU ini akhirnya disahkan menjadi undang-undang dalam sidang paripurna DPR pada Kamis (25/9/2014). Namun Undang-undang ini tak bisa serta-merta diterapkan karena Pemerintah harus menyiapkan implementasinya terlebih dahulu dalam jangka waktu lima tahun, yaitu hingga 2019. Muatan penting yang dapat dilihat adalah Pasal 4 yang menegaskan bahwa produk yang masuk, beredar, dan diperdagangkan di wilayah Indonesia wajib bersertifikat halal. Hal ini berarti bahwa tidak ada lagi produkproduk baik lokal maupun impor yang boleh beredar di Indonesia tanpa disertai sertifikat halal. Meski demikian harus disadari bahwa Kriteria sertifikasi halal sendiri sebenarnya cukup sederhana dan mudah berdasarkan UU JPH.

Pertama, harus dipahami bahwa UU JPH tidak mewajibkan bahwa seluruh produk yang beredar harus halal sesuai ajaran Islam. Ada pengecualian yang diatur dengan tegas bahwa pelaku usaha yang memproduksi produk dari bahan baku yang berasal dari bahan yang diharamkan dikecualikan dari kewajiban

\footnotetext{
${ }^{23}$ Republik Indonesia, Undang-undang No. 33 Tahun 2014 Tentang Jaminan Produk Halal. Menimbang huruf c.

${ }^{24}$ Republik Indonesia, Undang-undang No. 33 Tahun 2014. Menimbang huruf b dan d

${ }^{25}$ Lihat lebih lanjut dalam https://www.republika.co.id/berita/ekonomi/syariahekonomi/17/10/11/oxnnm1383-pengusaha-minta-uu-jaminan-produk-halal-ditinjau-ulang
} 
mengajukan permohonan Sertifikat Halal. Artinya hanya yang berbahan dasar halal saja yang wajib disertifikasi.

Kedua, sejak awal dalam UU JPH ditegaskan bahwa yang disertifikasi adalah bahan dan proses produksi dari produk. Di luar dari kedua hal tersebut bukan menjadi objek pengujian halal yang disertifikasi. Mengenai bahan baku, akan diatur lebih lanjut daftarnya melalui penetapan Menteri Agama berdasarkan fatwa Majelis Ulama Indonesia. Oleh karena itu sejak awal pelaku usaha dapat menilai sendiri apakah produknya menjadi objek sertifikasi halal atau bukan. Apalagi secara umum kriteria bahan yang halal telah disebutkan dalam UU JPH pada Pasal 17 hingga Pasal 20.

Ketiga, mengenai proses produksi hanya akan menguji agar lokasi, tempat, dan alat produksi wajib terpisah dengan lokasi, tempat, dan alat penyembelihan, pengolahan, penyimpanan, pengemasan, pendistribusian, penjualan, dan penyajian produk tidak halal. Kriterianya ada tiga yaitu dijaga kebersihan dan higienitasnya; bebas dari kontaminasi najis sesuai ajaran Islam; dan bebas dari kontaminasi bahan tidak halal.

Keempat, semua proses sertifikasi halal akan mengandalkan pada tahap awal berkas tertulis yang diajukan. Jika berkas lengkap, BPJPH akan mengirimkan auditor halal untuk menguji langsung di lokasi produksi sesuai berkas. Selama tidak ada perbedaan data yang tertera dalam berkas dengan yang ditemukan oleh auditor halal, maka proses uji halal produk akan berjalan lancer.

Kelima, bagi pelaku Usaha Mikro, Kecil, dan Menengah (UMKM) akan dimudahkan dengan fasilitas pendampingan khusus oleh Halal Center yang dapat dibentuk oleh LSM atau perguruan tinggi sehingga tidak akan membebani biaya sertifikasi. Logo halal sendiri akan berlaku selama 4 tahun dengan pemeriksaan berkala oleh auditor halal. ${ }^{26}$ Namun, terlepas dari hal tersebut maka yang lebih penting untuk difahami adalah bahwa keberhasilan jaminan produk halal sangat ditentukan oleh tiga faktor yaitu : Individu, masyarakat dan negara itu sendiri. Individu yang bertakwa akan berhati-hati memilih produk yang akan dikonsumsi, ketakwaan mencegahnya dari mengkonsumsi serta memproduksi barang haram

\section{b. Perlindungan Hukum Terhadap Konsumen (muslim)}

Secara normatif, hak-hak konsumen terakomodir di dalam UndangUndang No. 8 Tahun 1999 tentang Perlindungan Konsumen. Salah satu hak yang terakomodir adalah hak atas informasi yang jelas dan jujur tentang kondisi dan jaminan barang yang akan dikonsumsi. Secara tersirat, ketentuan ini juga

\footnotetext{
${ }^{26}$ http://www.hukumonline.com/berita/baca/lt5998e2b42365b/pahami-5-hal-berikut-agarpelaku-usaha-tak-langgar-uu-jaminan-produk-halal
} 
mengakomodir jaminan bagi konsumen untuk mengetahui apakah pangan yang akan dikonsumsi masuk dalam kategori 'halal' atau tidak. Asumsinya bahwa mayoritas konsumen di Indonesia adalah muslim, dengan begitu tuntutan untuk memenuhi hak informasi halal dari hari ke hari semakin tinggi.

Dalam sudut pandang ekonomi, prinsip yang senantiasa diperpegangi oleh pelaku usaha adalah pengeluaran sekecil-kecilnya untuk keuntungan yang sebesar-besarnya. Berdasarkan prinsip ini pula banyak oknum produsen/pengusaha yang mengejar keuntungan dengan segala cara, yang justru sangat merugikan konsumen. Belum lagi jika perbuatan tersebut merugikan umat Islam karena termasuk ke dalam kategori haram. Menurut Janus ${ }^{27}$ setidaknya ada empat perilaku produsen/pengusaha yang dapat merugikan konsumen yaitu :

1. Menaikkan harga. Hal ini terkait dengan keadaan kelangkaan dan monopoli suatu produk, bahwa konsumen tidak memiliki alternatif lain selain membeli produk tersebut

2. Menurunkan mutu. Hal ini juga terkait jika terjadi monopoli terhadap suatu produk

3. Dumping. Menurunkan harga jual produk di bawah biaya produksi, hal ini dimaksudkan untuk menjatuhkan pengusaha lain

4. Pemalsuan produk.

Adanya aturan terkait perlindungan konsumen dimaksudkan untuk menjamin dan melindungi kepentingan konsumen. Hukum perlindungan konsumen yang berlaku di Indonesia memiliki dasar hukum yang telah ditetapkan oleh pemerintah. Adanya dasar hukum yang pasti, perlindungan terhadap hak-hak konsumen bisa dilakukan dengan penuh optimisme. Pengaturan tentang hukum perlindungan konsumen telah diatur dalam Undang-Undang No. 8 Tahun 1999 tentang Perlindungan Konsumen. Berdasarkan Pasal 1 angka 1 UUPK disebutkan bahwa Perlindungan konsumen adalah segala upaya yang menjamin adanya kepastian hukum untuk memberi perlindungan kepada konsumen. Kepastian hukum untuk memberi perlindungan kepada konsumen berupa perlindungan terhadap hak-hak konsumen, yang diperkuat melalui undang-undang khusus, memberi harapan agar pelaku usaha tidak bertindak sewenang-wenang yang selalu merugikan hak-hak konsumen ${ }^{28}$.

\footnotetext{
${ }^{27}$ Janus Sidabalok, Hukum Perlindungan Konsumen di Indonesia, (Bandung, Citra Aditya Bakti, 2006), h. 3

${ }^{28}$ Happy Susanto, Hak-Hak Konsumen Jika Dirugikan, (Jakarta, VisiMedia, 2008), h. 4
} 
Secara garis besar, perlindungan konsumen dibagi atas tiga bagian yaitu :

1. Hak yang dimaksudkan untuk mencegah konsumen dari kerugian, baik kerugian personal, maupun kerugian harta kekayaan.

2. Hak untuk memperoleh barang dengan harga yang wajar

3. Hak untuk memperoleh penyelesaian yang patut terhadap permasalahan yang dihadapi ${ }^{29}$

Terkait hal tersebut, permasalahan yang dihadapi oleh konsumen muslim ternyata tidak sesederhana permasalahan yang dihadapi oleh konsumen lain, sebab produk yang dikonsumsi/dipergunakan harus sesuai dengan standar dan kriteria yang ditetapkan oleh agama yang meliputi halalan, thayyiban, mubaraqah, di samping adanya wilayah syubhat ${ }^{30}$. Oleh karenanya hukum perlindungan konsumen di Indonesia haruslah istimewa dan memang sangat dibutuhkan untuk menghidarkan konsumen dari kerugian akibat ulah pelaku usaha. Namun penegakan hukum perlindungan konsumen, bukan berarti secara serta merta dapat dikatakan bahwa konsumen telah terlindungi sepenuhnya, karena masih ada hal lain yang perlu mendapat perhatian, khususnya konsumen muslim, di mana konsumen muslim tidak hanya membutuhkan kesehatan fisik tapi juga kesehatan/ketenteraman rohani, yakni terbebas dari mengonsumsi barang-barang yang haram, baik haram karena zatnya maupun yang haram karena prosesnya.

Di samping keharaman zat dari suatu produk maupun keharaman karena prosesnya, masih banyak hal lain yang harus diperhatikan oleh pelaku usaha untuk memberikan perlindungan kepada konsumen muslim, agar konsumen tidak dirugikan. Di bawah ini dapat dikemukakan beberapa kegiatan usaha dan hal terlarang dalam perdagangan, yang tentu saja sebagian di antaranya terkait secara langsung dengan kepentingan konsumen. Usaha dan hal-hal terlarang yang

${ }^{29}$ Ahmadi Miru. Prinsip-prinsip perlindungan bagi Konsumen di Indonesia. (Rajawali Pers.2011), h.180

30 Syubuhat, atau Subhat merupakan istilah di dalam Islam yang menyatakan tentang keadaan yang samar tentang kehalalan atau keharaman dari sesuatu. Syubhat juga dapat merujuk kepada sebuah keadaan kerancuan berpikir dalam memahami sesuatu hal, yang mengakibatkan sesuatu yang salah terlihat benar atau sebaliknya. Dalam permasalahan kontemporer seringkali umat yang awam menghadapi permasalahan yang belum jelas dan meragukan sehingga dibutuhkan keterangan atau penelitian lebih lanjut, syariat Islam menuntut segala sesuatu dilakukan atas dasar keyakinan bukan keragu-raguan. Sering kali dibutuhkan fatwa dan ijtihad ulama untuk menentukan status hukumnya.

https://id.wikipedia.org/wiki/Syubhat 
dimaksud adalah: pelacuran dan peramalan nasib; perjudian; pengangkutan barang haram; menadah barang rampokan dan curian; jual beli dalam masjid; jual beli ketika azan jumat; menimbun; mengurangi ukuran, sukatan, dan timbangan; menyembunyikan cacat barang; banyak sumpah; najasy (reklame palsu); jual kawin; jual beli dengan lemparan batu; jual beli samar; persaingan sesama muslim; menghadang kafilah di luar pasar; orang kota menjadi makelar orang desa; menetapkan harga pasar; dan riba.

Apabila diperhatikan beberapa hal yang terlarang sebagaimana disebutkan di atas, maka secara garis besar dapat dibagi atas tiga bagian, yaitu haram secara umum, haram yang terkait dengan perlindungan konsumen dan haram yang terkait dengan persaingan usaha. ${ }^{31}$ Lebih lanjut menurut Ahmad Miru, bahwa Upaya memberikan perlindungan konsumen dari produk haram telah dilakukan dalam berbagai peraturan perundang-undangan, hanya saja masih dilakukan secara parsial sehingga tidak dirasakan sebagai perlindungan konsumen muslim karena nama peraturan perundang-undangan tersebut tidak secara jelas menyebutkan perlindungan konsumen muslim, berbeda dari Rancangan Undang-undang Jaminan Produk Halal yang dari namanya sudah tampak bahwa undang-undang itu nantinya akan memberikan perlindungan kepada konsumen muslim, sehingga seolah-olah undang-undang itulah yang merupakan ketentuan perundangundangan pertama yang memberikan perlindungan hukum kepada konsumen muslim $^{32}$

Terkait hal tersebut, salah satu wujud yang dapat dilihat khususnya bagi masyarakat muslim adalah terkait bermunculannya berbagai aturan yang langsung maupun tidak langsung memuat dan merinci kriteria "halal dan baik" bagi masyarakat muslim, juga sertifikasi halal pada berbagai produk (terlepas dari lembaga yang berwenang) ${ }^{33}$, termasuk ke dalam bagian ini adalah sertifikasi halal

\footnotetext{
${ }^{31}$ https://hukumperdataunhas.wordpress.com/2013/11/25/152/. Diakses tanggal 20 Mei 2018

${ }^{32}$ https://hukumperdataunhas.wordpress.com/2013/11/25/152/. Diakses tanggal 20 Mei 2018
}

${ }^{33}$ Pengaturan penggunaan produk halal di Indonesia, memiliki dua hal yang saling terkait, yaitu sertifikasi halal dan labelisasi halal. Sertifikasi halal adalah fatwa tertulis MUI yang menyatakan kehalalan suatu produk sesuai syariat islam melalui pemeriksaan yang terperinci oleh LPPOM MUI. Sertifikat halal ini merupakan syarat untuk mendapatkan izin pencantuman label halal pada kemasan produk dari instansi pemerintah yang berwenang (Badan POM). Adapun lebelisasi halal adalah perizinan pemasangan kata halal pada kemasan produk dari suatu perusahaan oleh Badan POM. Izin pencantuman label halal pada kemasan produk makanan yang dikeluarkan oleh Badan POM didasarkan rekomendasi MUI dalam bentuk sertifikat halal MUI. Sertifikat halal MUI dikeluarkan oleh MUI berdasarkan hasil 
bagi rumah-rumah makan, restoran maupun hotel-hotel yang menyajikan makanan sebagai bagian dari pelayanannya. Di samping itu pula, melabelisasi halal (kembali) terhadap produk-produk pangan (misalnya daging impor) yang dari negara asalnya telah mengantongi halal certifier akan tetapi dinilai belum kredibel dan masih meragukan untuk dikonsumsi oleh masyarakat muslim Indonesia. Semua usaha usaha tersebut perlu diapresiasi sekaligus dikritisi, sebab pada satu sisi perlindungan konsumen (khususnya muslim) telah mendapat perhatian, namun pada sisi lain bentuk pelaksanaan kongrit dari segenap aturan dinilai belum berjalan makasimal.

\section{PENUTUP}

Perlindungan konsumen tentu tidak cukup hanya mengandalkan ketentuan yang terdapat dalam UUPK maupun undang-undang serta peraturan lainnya, karena UUPK misalnya telah menentukan bahwa segala ketentuan peraturan perundang-undangan yang bertujuan melindungi konsumen yang telah ada pada saat undang-undang ini diundangkan, dinyatakan tetap berlaku sepanjang tidak diatur secara khusus dan/atau tidak bertentangan dengan ketentuan dalam undangundang ini $^{34}$. Oleh sebab itu terbuka kemungkinan, terbentuknya undang-undang baru yang pada dasarnya memuat ketentuan-ketentuan yang melindungi konsumen khususnya konsumen muslim, di mana UUPK merupakan payung yang mengintegrasikan dan memperkuat penegakan hukum di bidang perlindungan konsumen. Disamping kaum konsumen muslim perlu menerapkan sikap kehatihatian dan meningkatkan pengetahuan terhadap produk-produk yang ada di pasaran, dan lebih penting adalah sejauh mana pemerintah menjalankan dan mengawal, dan menegakkan peraturan yang dibuatnya.

pemeriksaan LPPOM MUI. Lihat. Aisjah Girindra, Pengukir Sejarah Sertifikasi Halal, (Jakarta, LP POM,2005), h. 69

\footnotetext{
${ }^{34}$ Lihat UUPK Pasal 64
} 


\section{DAFTAR PUSTAKA}

Al Qur'an

Ahmadi Miru, 2011. Prinsip-prinsip perlindungan bagi Konsumen di Indonesia. Jakarta. Rajawali Pers.

Aisjah Girindra, 2005. Pengukir Sejarah Sertifikasi Halal, Jakarta, LP POM,

Ali Mustafa Yaqub, 2013. Kriteria halal haram untukPangan, obat dan kosmetika menurut Al-Our'an dan hadis, Surakarta, Pustaka Firdaus.

Dedi Harianto, 2010, Perlindungan Hukum Bagi Konsmen Terhadap Iklan yang Menyesatkan, Bogor, Ghalia

Departemen Agama, Pedoman Produk Halal, Jakarta, Proyek Pembinaan Pangan Halal

Happy Susanto, 2008. Hak-Hak Konsumen Jika Dirugikan, Jakarta, VisiMedia,

Janus Sidabalok, 2006. Hukum Perlindungan Konsumen di Indonesia, Bandung, Citra Aditya Bakti

Kementrian Agama RI, Pedoman Libelisasi Halal, (Jakarta, Proyek Pembinaan Pangan Halal Dirjen Binmas Islam, 2003), h. 7

Murjani, Sistem Jaminan Produk Halal dan Thayib di Indonesia: Tinjauan Yuridis dan Politis. Jurnal Fenomena Volume 7, No. 2 Tahun 2015

Ujang Sumarwan, 2011, Perilaku Konsumen, Teori dan Penerapannya Dalam Pemasaran, Bogor, Ghalia

Sayyid Sabiq, 1999, Fikih Sunnah, Jilid 13 Bandung, al Ma'arif

Sumber Lain :

http://www.hukumonline.com/berita/baca/lt5998e2b42365b/pahami-5-halberikut-agar-pelaku-usaha-tak-langgar-uu-jaminan-produk-halal

https://dalamislam.com/makanan-dan-minuman/makanan-halal/makanan-halal

https://food.detik.com/info-halal/d-3384854/ini-klarifikasi-mui-terkait-kehalalanproduk-bumbu-penyedap-dan-mie-goreng-instan)

https://hukumperdataunhas.wordpress.com/2013/11/25/152/

https://id.wikipedia.org/wiki/Syubhat

https://www.republika.co.id/berita/ekonomi/syariahekonomi/17/10/11/oxnnm1383-pengusaha-minta-uu-jaminan-produkhalal-ditinjau-ulang 